\title{
Assessment of Teachers' Technological and Pedagogical Knowledge of Integrating ICT in teaching English in Secondary Schools in Nairobi County, Kenya
}

\author{
Michael Odoyo Ogalo ${ }^{1^{*}}$, Carolyne Omulando ${ }^{2}$, Peter Barasa ${ }^{2}$
}

\author{
${ }^{1}$ Moi University, Department of Curriculum Instruction and Education Media, P. O. Box 3900, 30100, Eldoret, Kenya \\ ${ }^{2}$ Professor, Alupe University College, School of Education and Social Sciences, P. O. Box 845-50400, Busia, Kenya
}

DOI: $10.36347 /$ sjahss.2022.v10i01.003

| Received: 07.12.2021 | Accepted: 10.01.2022 | Published: 24.01.2022

*Corresponding author: Michael Odoyo Ogalo

Moi University, Department of Curriculum Instruction and Education Media, P. O. Box 3900, 30100, Eldoret, Kenya

The purpose of this study was to assess teachers' technological and pedagogical knowledge of integrating ICT in teaching English in secondary schools in Nairobi County, Kenya. The study was guided by two frameworks: Technological Pedagogical and Content Knowledge (TPACK), and Teacher Cognition. The study employed an explanatory sequential mixed-methods approach to collect both qualitative and quantitative data. The study adopted a descriptive survey research design, and pragmatic world view as a philosophical orientation. The sample consisted of 20 secondary school teachers of English from Nairobi County. Simple random and purposive sampling techniques were used. Data was collected using an interview schedule and a teacher questionnaire. Data were analysed using descriptive statistics: frequencies, percentages, means, standard deviations and presented in tables and short descriptions and content analysis procedures and presented in narrations based on thematic areas derived from the study variables. The findings revealed among other things that, $75 \%$ of the teachers of English sampled lacked TPACK to effectively integrate ICT in their teaching, the training required by teachers of English to integrate ICT in their teaching and the resources needed to deliver this were inadequate in many schools under study. The study concluded that: teachers of English needed sufficient technological pedagogical knowledge and adequate ICT skills to effectively integrate ICTs in their teaching, the aspirations of national educational authorities because of establishing ICT competencies does not automatically result in changes in classroom practices. The study recommended that teachers be provided with professional development as a continuous process on the integration of ICT in teaching; underscoring the importance of the continued teacher development in ICTs to enhance English language teaching. The study further challenges policymakers in the secondary school context to develop an ICT plan including vision building professional, ICT-based English curriculum and evaluation to frame ICT training in a broader vision of ICTs for teaching and learning.

Keywords: Technological knowledge, Pedagogical knowledge, ICT integration, Teacher knowledge, TPACK, Teacher cognition.

Copyright (C) 2022 The Author(s): This is an open-access article distributed under the terms of the Creative Commons Attribution 4.0 International License (CC BY-NC 4.0) which permits unrestricted use, distribution, and reproduction in any medium for non-commercial use provided the original author and source are credited.

\section{INTRODUCTION}

The utilization of information and communication technology (ICT) in education has the potential to enhance the quality of teaching and learning, research productivity of teachers and students, and the management and effectiveness of institutions, hence the value of ICTs to English language teaching. Research has found that teachers require specialized knowledge to competently and effectively integrate ICTs into their instructional processes and that the use of ICTs for teaching could be dependent on the teacher's cognition, hence the question, do teachers in Nairobi County use ICT for teaching English given the importance today? What is their cognition? However, research has indicated that it is not the tool itself that leads to pedagogical change but, rather how the tool is marshalled by teachers. Researches are also clear that it is teachers' beliefs, perceptions of, and attitudes towards novel technology that informs how they make use of these ICTs in their lessons. Teachers' decisions to integrate ICTs in the English language classes could be linked to teachers' cognitions hence the question, do teachers in Nairobi County use ICTs for teaching 
Michael Odoyo Ogalo et al., Sch J Arts Humanit Soc Sci, Jan, 2022; 10(1): 9-23

English given the importance today? What is their cognition?

The introduction of ICT in education is part of the more fundamental objectives to improve education globally and to make it accessible to everyone. Information and Communication Technology is a diverse set of technological tools and resources used to communicate, and to create, disseminate, store, and manage information (Blurton, 2002). Extended synonym for Information Technology (IT) include the integration of technology as computers, the Internet, broadcasting technologies (radio and television), and telephone with various services and applications associated with them which enable users to access, store, transmit, and manipulate information (Buttner, 2014). The utilisation of ICT in teaching has the possibility of enhancing the quality of teaching and learning, teachers' research productivity, students, and the management and effectiveness of institutions (Kashorda, Waema, Omosa, \& Ilori, 2007).

Lankshear and Knobel (2006) and de Winter, Winterbottom, and Wilson (2010) state that ICT has enabled new and more efficient ways of doing things and provides new tools that facilitate students' construction of learning. Yet studies show that ICT use, particularly by teachers, remains limited (European Union, 2013), therefore developing an understanding of how and why ICT is used and not used continues to be of interest. Research has suggested that using ICT in education enables learners to take a more energetic role in their studies rather than be passive observers or listeners (Gao \& Hargis, 2010; Saleh, 2008), and that is why there was a need to study the situation in Nairobi County. Information and communication technology (ICT) is also perceived to have many advantages in education including, learning and teaching English, pursuing problem-solving skills, fostering collaborative learning, providing flexible learning opportunities and increasing productivity (Bitter and Legacy, 2008; Chambers, 2011). Furthermore, ICT is considered important for following the effectiveness of teaching and learning in schools (Lin, Wang and Lin, 2012). Consequently, with the potential that it offers, ICT has become an important part of educational reform efforts. Many countries have allocated substantial budgets for ICT implementation in education. Since the late 1990s, many governments have developed strategic plans to increase their investments in ICT in their education systems. In 2011, the Organisation for Economic Cooperation and Development found that several governments are making sizeable investments in ICT.

Australian government estimated that about $\$ 8$ billion was invested in ICT in education in 2008 (Lane, 2012). In 2006, the United States Department of Education reported spending more than $\$ 9.5$ billion on educational technology in public schools (Brunk, 2008). Like the Australia and United States, the United
Kingdom has also made substantial investments in educational technology. British Educational Communications and Technology Agency (BECTA, 2009) estimated that an overall figure for ICT investment in the United Kingdom between 2008 and 2009 WAS at $£ 880$ million. The importance and benefits of ICT have also been recognised by many European countries. In the last decade, many school subjects have seen the implementation of ICT into the educational process (Balcon, 2003).

Similarly, Saudi Arabia has realised that the use of computers and information technology tools in academic settings is very important (Almuqayteeb, 2009). In 2007, Saudi Arabia's King Abdullah began to pursue major reforms to the Saudi academic system. One of the most important of these reforms is King Abdullah's Public Education Development Project (Tatweer) which was seeking to equip classrooms with ICT equipment including laptop computers, projectors, and interactive whiteboards. In addition to the equipment, nearly 400,000 teachers in various subjects received the training necessary to use this equipment. This project was launched with a budget of SAR 9 billion over six years (Ministry of Education, 2006). In 2005, Kenya began to pursue major reforms to the Kenya education system. One of the most important reforms was on the ICT master plan which was seeking to equip classrooms with ICT equipment including laptop computers, with the first phase of laptop computers supplied to some primary schools for standard one pupil (GoK 2016). The Government has put in place the National ICT Policy and E-Government Strategy that provides guidelines for the transformation of Kenyan into a digital society. In both documents, the Government recognises that an ICT literate workforce is a foundation on which the nation would become a knowledge-based economy. With these considerable investments in ICT for education, it is prudent to question to what extent have Kenyan English language teachers integrated ICTs into their classroom practices? Does the reality on the ground match the expectations? Although few studies have produced useful information, they do not provide a deep insight into how ICT is being used in Kenyan classrooms and the rationale for not integrating ICT in the educational processes. The study thesis alternatively, and more comprehensively, considered the role of teachers' technological, pedagogical and content knowledge (TPACK) in the effective integration of ICT in teaching. To do this, this research, embraced the TPACK model (Koehler and Mishra 2008), an important theoretical framework, that views technological, pedagogical and content knowledge of a teacher instead of facile dimensions of the utilisation and explored teachers' cognitions about integrating ICT in teaching. TPACK is described in greater detail later in Section 2.11. As implementers of innovations, teachers play an important role in the process of technology adoption (Dexter, Anderson, and Becker 
Michael Odoyo Ogalo et al., Sch J Arts Humanit Soc Sci, Jan, 2022; 10(1): 9-23

1999). At the heart of what teachers do lay their cognitions. Therefore, the current study provides a better understanding of Kenya secondary school English language teachers' cognition about integrating ICT in their classroom practices

\section{a) Teacher Knowledge about the use of ICT}

Knowledge is seen as a distinctly key element of teachers' ICT characteristics (Van Break, 2001). The absence of teacher knowledge or capabilities linked to the application of ICT for instructional purposes has been spotted as a crucial obstacle to the successful ICT application (Hew \& Brush, 2007; Bingimlas, 2009; Chen, Looi, \& Chen, 2009). Williams, Coles. Wilson, Richardson \& Tuson (2002) asserted that knowledge and competency were prerequisites for teachers at an early stage of ICT establishment. It is, however, critical to note that focusing on teachers' technical knowledge alone is deficient to achieve successful technology execution (Lloyd, 2010). Similarly, according to the TPACK theory, teachers require exclusive of just technical know-how (Mishra \& Koehler, 2006). TPACK was established by Koehler and Mishra (2005) as a conceptual framework to relate the form of knowledge teachers require to competently utilise technology in their instructions (Koehler, \& Mishra, 2007). This framework recommends that interrelations and competencies exist among the three fundamental constructs of knowledge (technology, pedagogy, and content) (Mishra \& Koehler, 2006; Koehler \& Mishra, 2008). As these three elements of Knowledge traverse, this will steer an understanding of teaching content with suitable technological methods and computers. The convergence of all the elements is the basis of the model which is the TPACK components, Mishra \& Koelhar (2006) and Voogt, Fiser, Pajerarobin, Tondeur \& Van Break, (2012) describe this model of teacher knowledge as including content, the subject specialist knowledge; pedagogy, knowledge of techniques of teaching and learning; and pedagogical content knowledge, based on Shulman's definition (Shulman, 1986). This definition sets out the knowledge used to make the subject comprehensible to others and the requirements for teacher knowledge. The TPACK component could be defined as "a teacher's knowledge of how to coordinate and combine the use of subjectspecific activities using emerging technologies to facilitate student learning" (Cox \& Graham, 2009). Teachers make use of a range of knowledge to effectively do their job and the integration of technology into teaching and learning involves a knowledge base for teachers that is new and therefore needs to be developed through appropriate professional development (Mishra \& Koelhar, 2006; Loveless, 2011). Mishra \& Koelhar (2006) explain this concept as the qualities of teacher knowledge required to integrate technology within pedagogy. For ICT to support teaching and learning, pedagogy and what teachers need to know to successfully incorporate the technology must be considered (Mishra \& Koelhar, 2006).
This is known as Technological Pedagogical Content Knowledge (TPCK), the TPACK theory has been applied to assess teachers' knowledge regarding the utilization of educational technologies in more developed Western nations (Cox \& Graham, 2009; Lee \& Tsai, 2010; Chai, Koh, \& Tsai, 2010; Archambault \& Barnett, 2010). However, the relevancy of this framework to Kenya teachers of English who live in a different cultural and economic environment is not known. Since Kenya Government has pursued considerable strides towards ICT blending in education, there is a strong desire to establish teachers' cognition and integration of ICT in English language classroom practices. The framework presupposes that teachers' use of ICT has a robust connection with their TPACK that is, teachers having "strong" TPACK will be more successful with the integration of ICT in their classrooms. It, therefore, seemed reasonable to investigate the usefulness of ICT integration from the perspective of TPACK theory. This study presumed that the more TPACK a teacher has, the more successful ICT would be applied in their English classrooms. This, in turn, is equivalent to progression into the more developed stages of the LoTi Digital Age Framework, not part of this study.

\section{STATEMENT OF THE PROBLEM}

Information and communications technology (ICT) is viewed as very crucial in enhancing the effectiveness of teaching and learning in schools (Lin, Wang, \& Lin, 2012). Consequently, ICT in education has become an important part of educational reform efforts worldwide. Although ICT is becoming prevalent in schools, and children are increasingly growing up with ICT, teachers' use of ICTs for teaching and learning continues to be a concern for educators and researchers (Jinoyyiannis, 2010; Polly, Mims, Shephard, \& Inan 2010). The spread of researches has revealed that many teachers are not utilising ICTs successfully in their English instructions (Wozney, Venkatesh, \& Abrami, 2006). Despite enormous contribution and immense economic expenditure to integrate ICT in education, the Ministry of Education (2012) has acknowledged that the education sector has not attained the expected objectives of ICTs integration in schools. Most of the ICT projects started in schools either have not been successful or have stalled and hence have ended without attaining the expected objectives (Njagi and Omboko, 2013). Whereas this is the trend, in the Competency-Based Curriculum launched in 2016 in Kenya, the use of ICTs is at the heart of the instructional delivery process. Hence, unless this trend is drastically reversed, Kenya's bid to attain both the ICT strategic plan by 2020 and vision 2030 will be jeopardised. Similarly, research has demonstrated that teachers are more likely to integrate technologies if they identify the usefulness of technology tools that support their pedagogical beliefs (Zhao \& Frank, 2003). In addition, teachers' values and 
Michael Odoyo Ogalo et al., Sch J Arts Humanit Soc Sci, Jan, 2022; 10(1): 9-23

ability to perceive the usefulness of technologies are seen as crucial for classroom technology integration (Ertner, 2005). Previous studies on ICT in education have focused mostly on basic ICT as a subject in the curriculum and not as a tool for teaching, a study by Wanjala, (2016) for example, examined the integration of ICT in Mathematics.

A study by Manyasi, (2012) focused on English language teachers' cognition of the teaching of reading for national values in Kenya and did not look at ICT integration. Fewer studies have examined teachers' knowledge regarding the application of ICT in English language teaching and in particular Nairobi County, Kenya. Existing studies on teacher cognition of the ICT integration in teaching and learning examined more on practice regarding technology use outside Kenya (Suwannasom, 2010; Attia, 2011) and are either quantitative or qualitative in their approaches, focusing only on the outcome, and others on factors influencing integration of ICT use (Brindley, et al., 2010). Therefore, by examining secondary school teachers of English in Nairobi County using a mixed-methods approach and applying the TPACK and teacher cognition frameworks, the researcher intended to provide a broader understanding of English language teachers' cognitions in teaching using technology. It is for this reason that this study sought to establish teachers' cognition of the integration of ICT in teaching English in secondary schools in Nairobi County, Kenya.

\section{III.OBJECTIVE OF THE STUDY}

The study sought to assess technological and pedagogical knowledge (TPK) of a teacher of English for ICT integration in teaching in secondary schools in Nairobi County, Kenya.

\section{IV.SIGNIFICANE OF THE STUDY}

This study sought to assess teachers' technological and pedagogical knowledge (TPK) of the integration of ICT in teaching English in secondary schools in Nairobi County, Kenya. The findings from this study raised the awareness of teachers of the English language of their pedagogical practices in implementing new technologies in English language instruction. The study findings would help the management of schools in enacting and/or amending pertinent policies to see to it that the application of ICT in pedagogy by the entire teachers is maximized, hence minimizing the wastage arising from underutilization of ICT resources.

The study findings could also be used by English language teacher educators, education policymakers and stakeholders, language educational institutions and curriculum developers to improve teachers' awareness of the extent to which knowledge is relevant to the application of ICTs in pedagogy. Furthermore, the findings of this study will augment the knowledge body by contributing to the literature on how knowledge relates to the use of ICTs in pedagogy. Therefore, the findings of this study have contributed to the existing theory that teachers' TPACK constructs and cognitions influence their choice of teaching strategies and subsequently influence their practice with ICTs in the English classrooms, and have provided "behind the scenes" information that explains why teachers of English choose to use or not use particular novel pedagogical strategies to integrate ICTs in their teaching. Therefore, these contributions are significant to the theory of teachers' professional work and the uses of ICTs in the teaching practicum. Furthermore, the findings of this study have given more attention to the level of ICT integration to increase and encourage the use of ICT tools, in particular in secondary schools in Kenya. Finally, the results of this study have contributed to the growing knowledge base regarding ICTs integration in teaching English in secondary schools in Kenya.

\section{REVIEW OF RELATED LITERATURE}

Since knowledge does not exist in a vacuum, the researcher reviewed several pieces of literature. The purpose was to refine the research ideas, demonstrate awareness of the current state of knowledge on the study, linking it with the study in a wider context. This chapter presents an analysis of the literature that has informed the development of this study. The chapter reviews both the empirical and related literature. The focus of this study involves not only English language teachers but also their cognitions and attitudes towards ICT integration in English language instruction in the Kenya context. The sources of literature include Review articles, books, journals, research papers, thesis reports, case reports, and web-based publications. A question that is often posed is: Does pedagogy shape technology, or does technology shape pedagogy? The evidence available to us suggests a close relationship between teacher cognition on one hand and the role of ICT in teacher education on the other. Belland (2009) remarks that since prior learning experiences affect the way information is internalised, the absence of a technology element in schooling years might influence teachers' perceptions of the role of ICT in education, and cause them not to use it in their subsequent teaching. Belland (2009), Ertmer \& Ottenbreit-Leftwich (2010), affirm that teacher-candidates need to be placed in authentic educational settings where they witness technology being used and get the chance to employ it in teaching. In other words, they need to "experience" teaching with technology in real contexts for more efficient technology integration afterwards. Pre-service teachers' cognitions act as a filter through which they internalise their teacher education experiences, and without recognition of these established cognitions very little technology integration will take place (Ertmer, 2005; Tondeur, Hermans, Van Beck \& Valcke, 2008; Inan, Lowther, Raos \& Strahl, 2010). If we assume that 
Michael Odoyo Ogalo et al., Sch J Arts Humanit Soc Sci, Jan, 2022; 10(1): 9-23

learning occurs through constant interaction between established knowledge and new experiences, then addressing former beliefs and unpacking prior experiences become a priority for teacher educators (Borg, 2009). Researchers have argued that there is nothing inherent in the technology that leads to reforms in pedagogy and that as a tool; its value lies in how it is used by the teachers themselves (Ferding, 2006). In support of the same argument, Bruce (2002) states: "Unfortunately, new technologies are no panacea for problems in education and by themselves, they at most enable, rather than create, change. It is ironic that the research showing how powerful computers can ultimately bring us back the idea that it is the teachers who make the difference" (p. 17). Research from different educational settings across the world supports this argument. It suggests that ICT does not embody any specific pedagogy and that teachers use technology following their cognitions. Niederhauser \& Stoddart (2001) conducted a US-based study on the relationship between teachers' beliefs and their use of educational software. The researchers concluded that ICT itself does not represent a specific educational approach as teachers used computer-based material to support their own pedagogical beliefs, which were reflected in a wide array of educational approaches. Similarly, a study in a secondary school setting in Greece demonstrated that teachers integrated technological tools to support their traditional approaches of teaching, which placed great emphasis on the central role of the teacher and the testdriven curriculum (Demetriadis, Barbas, Molhides, Paligeoogiou, Psillos, Vlahavas, Tsoukalas, \& Pombortsis, 2003). In the same vein, Zhong \& Shen (2002) examined two technology-based secondary EFL classrooms in China. Their study revealed that innovations had no significant effect on the dynamics of teaching and learning. The teachers remained the centre of interaction within traditional settings. As ICT was used to support centuries-old educational practices, it only changed the physical look of classrooms. The researchers underscored the importance of targeting teachers' pedagogical beliefs as a necessary precondition for effective technology integration.

Lam (2000) also emphasised teachers' beliefs as key to integration. In her study of Canadian second language teachers, she demonstrated that those teachers who avoided using innovations, did so not because of technophobia, but because they were not convinced of the educational value of technology. Finally, based on research into the use of technology in Italian schools, Gobbo \& Girardi (2001) stipulated that although most of the teachers held positive attitudes toward ICT, they were unwilling to replace their traditional teaching routines. The researchers explained that the findings of their study do not support the common view that introducing technology into classrooms changes teachers' established approaches to teaching. It is generally accepted that successful technology integration requires an appropriate understanding of the role of technology and teachers in technology-mediated classrooms. Often researchers mention that technologyenhanced teaching works well when teachers' teaching philosophy and methods focus on learner-centred teaching and constructivist teaching practices (Judson, 2006). Constructivist pedagogy has significant implications for the use of technology that promote meaningful learning, increase students' motivation to learn, and facilitate thinking and knowledge construction. Thus, technology is used to mediate students' exploratory learning and knowledge construction than for the transmission of knowledge, it is something that students learn 'with' not 'from'. However, it is by no means certain that technology causes teachers to adopt constructivist beliefs. In their view, if teachers decide to use the computer in a constructivist manner, they do so, not because of features in the technology, but based on their knowledge and expertise.

Judson (2006) surveyed to measure 32 classroom teachers' beliefs about instruction. The teachers were also directly observed and rated with the Focus on Integrated Technology: Classroom Observation Measurement (FIT: COM), which measures the degree to which technology-integrated lessons are aligned with constructivist principles. Results revealed no significant relationship between instructional practices and teachers' stated beliefs. It was found that although most teachers identified strongly with constructivist convictions in the survey, they failed to exhibit these ideas in their practices.

Tondeur, Hermans, Van Beck, \& Valcke (2008) investigated the relationship between primary teachers' educational beliefs and their typical approach to computer use in the classroom. The results pointed at a specific relationship between teachers' belief profiles and how computers are used in the classroom. It was found that teachers with a traditional teaching profile are more likely to use computers in drill-and-practice activities, while teachers with a constructivist profile are more likely to give students more freedom when the computer is used to research and process information. This means that teachers would show traditional or constructivist use of technology because they already hold these beliefs in their classroom practices. Several studies explain that teachers who use computers do so because their conceptions of using ICT fit into their existing teaching beliefs or belief system (Sugar, Crawley, \& Fine 2004). It is also found that teachers' educational beliefs are indicators of their classroom behaviours and how they employ an instructional tool, including technology (Tondeur et al., 2008).

Cope and Ward (2002) interviewed a group of high school teachers to find out about their perceptions of learning technologies. A phenomenological research approach was used to examine the importance of teacher perceptions on the integration of learning 
Michael Odoyo Ogalo et al., Sch J Arts Humanit Soc Sci, Jan, 2022; 10(1): 9-23

technology. They further noted that successful integration is more likely to occur when teachers perceive technologies as tools that encourage students to use deep learning approaches which focus on interrelating aspects of the content being studied. This is supported by Egbert (2008) who indicates that effective technology-based learning tasks would take place when teachers focus on the following aspects: learning goals, training and support, times to learn relevant technologies, resources, and using technology only when appropriate. To conclude this section, effective technology practices can be established by teachers designing language instruction that provides opportunities for students to use technology to enhance their learning according to their abilities, skills, and learning objectives.

Felix (2003) states, we interpret best practice to mean using the most appropriate tools to their best potential to achieve sound pedagogical processes and outcomes. Teachers should ensure that the use of technology involves the practice of using technology in ways that are both curriculum-based and meaningful for students' learning. In terms of best practices in using technology in language teaching,

Hoopingarner (2009) proposes that technology should be used to "replace some aspects of teaching, augment aspects of teaching and learning, and transform the learning experiences" (p.233). Kerr (1991) confirms that "if technology is to find a place in classroom practice, it must be examined in the context of classroom life as teachers live it" (p.259-260). Similarly, Attia, (2011) postulates that technology in the classroom practice must be examined in the context of classroom life as teachers live it. It can be posited that technology use in language classrooms can reach the maximum potential when teachers see technology as a tool that can enhance teaching and learning by providing additional opportunities for language practice, and serve as a platform for extended technology and relate it to their classroom practices is thus crucially important. Information and communication technology (ICT) has progressively been blended into almost every aspect of life and society. Several institutions have recognised considerable development as a result of the brisk growth of ICT (Zhang \& Aikman, 2007). The education sector has also experienced major changes as a result of the implementation of ICT. In the beginning, computers first featured in classrooms in the early 1980 s and educators unearthed an indispensable tool for teaching students.

A study proposes that ICT will continue to play a crucial role in educational contexts for generations to come (Bransford, Brown, \& Cooking, 2002). Technology imparts numerous alternatives for underpinning learning (Lefebvre, Deaudelin, \& Loiselle, 2006). Computers began to appear in school and university classrooms in the more advanced countries around the early 1980s while broadband connections to schools and universities became commonplace in wealthier countries in the second half of the 1990s. In developing countries, this was more limited. The largest investments in ICT have been in the United States of America whose budget for the use of technology in schools is enormous. The US Department of Education has invested up to US\$ 1 billion in the use of technology in public education. Global investments in ICT to improve teaching and learning in schools so far have been initiated by many governments. For example in the United Kingdom, the government spending on educational ICT in 2008-09 was $£ 2.5$ billion (Nut, 2010). In the United States, the expenditure on schools and higher education institutions was $\$ 6$ billion and $\$ 4.7$ billion respectively in 2009 (Nut, 2010).

In New Zealand, the government spends over \$ 410 million every year on schools ICT infrastructure (Johnson, Calvert \& Raggert, 2009). Despite all these investments in ICT infrastructure, equipment and professional development to improve education in many countries. The question is what could be the issues behind such arguments? It is, generally recognised that the adoption of computers in education has progressed, from the acquisition of basic computer skills, computeraided teaching, communications and research, to usage in every subject. This has been accelerated by the convergence of computer and telecommunication technologies, particularly e-mail and the Internet. This progression has been a result of various efforts and a wide variation on the levels of ICT integration to the education curriculum, as determined by the social and economic conditions of individual countries and regions. Certainly, education and training play a critical role in social and economic development considering that one of its goals is to contribute positively in building the human capacity necessary to achieve the social pillar objectives besides achieving Education for All (EFA) goals by 2015 now behind us. The ministry of education science and technology of Kenya however recognises several challenges in the delivery of education services to achieve these goals which include the need to ensure improved: access, equity and quality that require enhanced planning, management and appropriate interventions (MoES\&T, 2012). To meet these challenges, there must be an effective Educational Management Information System (EMIS) infrastructure, which is currently being rolled out to support the processing, use, sharing and dissemination of available data and information at all levels. In Kenya, under Vision 2030 and Medium Term Plan (MTP), the government aims to ensure 20,000 computers are provided to schools as a flagship project in the education sector in addition to the current efforts by the Ministry to channel more resources towards providing adequate ICT infrastructure. In line with this, the Ministry of Education proposed a detailed costing of 
Michael Odoyo Ogalo et al., Sch J Arts Humanit Soc Sci, Jan, 2022; 10(1): 9-23

providing computers to schools based on the ratio of one laptop per teacher and one desktop per fifteen learners between the years 2010-2015, again now behind us. Table 1 gives a summary of costs (in Millions Kenya Shillings) for the duration 20102015.Technological knowledge and skills, or "competence" as some researchers (Albirini, 2006) refer to it, have been considered as an important requirement for teachers to achieve successful ICT integration in education. Previous research studies have shown that a large proportion of teachers' knowledge and skills about ICT as the main barrier to effective use of ICT (Becta, 2004; Balanskat et al., 2006; Hew \& Brush, 2007).

Albirini (2006) explored in his study the relationship between teachers' computer attitudes and five independent variables including teachers' computer competence. The results revealed that most of the respondents had very limited competence regarding the use of computers for instructional purposes. The researcher asserted that irrespective of the availability of technological equipment, it would not be used unless teachers have sufficient knowledge and skills to integrate technology into educational practices. The literature also shows that relationships exist between teachers' knowledge and skills and other teacher-related factors. Newhouse (2002) indicated that many teachers who lack the knowledge and skills to use computers are also not enthusiastic about the changes associated with bringing computers into their classroom practices. According to Becta, (2004) when teachers lack technical skills, they are likely to be anxious "about possible technical problems, as they would have less of an understanding of how to avoid or solve such problems independently" (Becta, 2004, p.21). Teachers' confidence to integrate ICT into teaching practices is another factor associated with teachers' level of knowledge and skills. Albirini (2006) indicated that teachers' lack of knowledge leads to their lack of confidence to integrate computers in education. Similarly, when responding to Becta's survey, most teachers who stated that their lack of confidence was a barrier, also indicated that they had limited knowledge in the area of ICT (Becta, 2004). Furthermore, teachers' attitudes towards computers are significantly influenced by teachers' computer competence (Albirini, 2006).

Al-Oteawi (2002) found that teachers who demonstrated negative or neutral attitudes towards the use of ICT in teaching practices lacked knowledge and skills about ICT. Apart from the need for technological knowledge and skills, some research studies emphasise the importance of other types of knowledge and skills; one is technology-related classroom management. Technology-related classroom management skills are those skills of managing ICT resources in classrooms. Teachers need to have specific management skills allowing them to know how to organise their classrooms effectively so that their students have equal chances to use ICT equipment, or what to do if their students experience technical problems when working on this equipment (Hew and Brush, 2007). Knowledge and skills have also been emphasised for the successful integration of ICT also known as technology-supported pedagogical knowledge (Hughes, 2005; OttenbreitLeftwich, 2010). This type of knowledge has been referred to as teachers' understanding of the link between the technologies being utilised and instructional strategies. Koehler \& Mishra, (2009) further added content knowledge resulting in TPACK, meaning teachers' knowledge of using technology to support pedagogical techniques in teaching specific content subject

Hughes (2005) contended that teachers need to be provided with a technology-supported pedagogical knowledge and skills base, so they can refer to it when they plan to utilise ICT in their teaching processes. According to Hew and Brush (2007), teachers' unfamiliarity with the pedagogy of using ICT may be considered as a barrier to effective ICT integration. Hew and Brush noted that professional development programmes have focused mainly on how to operate ICT equipment. Distinctly, teachers' knowledge and skills are crucial predictors for ICT integration in teaching. Nevertheless, teachers are required to not only be technologically knowledgeable; they also call for prospering other types of knowledge such as TPACK (Koehler and Mishra, 2009). Balanskat et al., (2006) suggested that teachers' level of knowledge is directly linked to the quality and quantity of teachers' professional development programmes. These programmes need to consider activities around pedagogical and content training rather than simply training teachers in skills of using ICT resources (Becta, 2004). Change in teachers' understanding and abilities, professional training content needs to be significant to the aspirations of teachers and classroom practices (Hew \& Brush, 2007). In particular, to revamp teachers' technology-supported pedagogical skills, opportunities should be availed for teachers to engage in vigorous learning; grounding learning experiences in contentconnected technology examples (Hew \& Brush, 2007). The successful integration of ICT in education is strongly linked to the understanding of effective pedagogical practices (Murphy, 2006). A more elaborate understanding of the role of teachers' knowledge and how it could enhance successful ICT integration, is discussed in section 2.7 an important theoretical framework, that is, the TPACK theory.

Technological pedagogical knowledge (TPK) is how teaching and learning change when particular technologies are used. It is knowledge of the pedagogical affordances and constraints of a range of technological tools as they relate to disciplinary and developmentally appropriate pedagogical designs and strategies. An important part of TPK is developing creative flexibility with available tools to re-purpose 
Michael Odoyo Ogalo et al., Sch J Arts Humanit Soc Sci, Jan, 2022; 10(1): 9-23

them for specific pedagogical purposes (example MS Office designed for English language environment, Web-based technologies such as blogs or podcasts are designed for purposes of communication and social networking. Teachers need to reject functional fixedness, develop skills to look beyond the immediate technology and "reconfigure it" for their pedagogical purposes.

Once again, here is the opportunity to "reconfigure" Web 2.0 tools for their use in the English language classroom. The teacher's own pedagogical beliefs and values play an important part in shaping technology-mediated learning opportunities. It is not yet clear from the research literature whether this results in technology being used as a 'servant' to reinforce existing teaching approaches, or as a 'partner' to change the way teachers and pupils interact with each other and with the tasks. Teachers need extensive knowledge of ICT to be able to select the most appropriate resources. They also need to understand how to incorporate the use of ICT into their lessons; they may need to develop new pedagogies to achieve this.

According to Koehler and Mishra (2009), TPK is "an understanding of how teaching and learning can change when particular technologies are used in particular ways" (p.65). Cox (2008) on his study gave a comprehensive definition of TPK as "a knowledge of the technologies that may be used in a generic pedagogical context, including the affordances and constraints of those technologies, and how those technologies influence or are influenced by the teacher's pedagogical strategies and student learning" (p. 76). It seems that TPK is the understanding of how to use technology to support general teaching strategies without reference to specific content. With this type of knowledge, teachers need to be flexible, creative, and open-minded in seeking technology to improve their students' learning and understanding. This is because most popular emerging technologies are not developed for educational purposes. Therefore, teachers need to have TPK that allows them to recondition these technologies for particular pedagogical implementations. Koehler \& Mishra, (2008) suggested that teachers require to "look beyond the immediate technology and 'reconfigure' their pedagogical purposes" (p. 17).

\section{METHODOLOGY}

This study utilized a mixed-methods approach. The study employed an explanatory sequential mixedmethods approach to collect both qualitative and quantitative data. The study adopted a descriptive survey research design, and pragmatic world view as a philosophical orientation. The target population consisted of practicing public secondary school teachers of English. The sample consisted of 20 secondary school teachers of English from Nairobi County. Simple random sampling was used to select 10 secondary schools. Two teachers were purposively selected from each secondary school. Data was collected using an interview schedule and a teacher questionnaire. Quantitative data were analysed using descriptive statistics: frequencies, percentages, means, standard deviations and presented in tables and short descriptions; while qualitative data was analysed using content analysis procedures and presented in narrations based on thematic areas derived from the study variables.

\section{FINDINGS AND DISCUSSIONS Technological Pedagogical Knowledge of a Teacher of English for ICT Integration}

In this research question number three, the researcher sought to investigate the technological pedagogical knowledge (TPK) of a teacher of English for ICT integration. Teachers were asked to answer 22 Likert-scale items measuring their levels of technological pedagogical knowledge for the ICT integration. The results of descriptive (IBM SPSS Statistics for software) analysis (Means, Std. Deviation, Frequencies and Percentages) were presented in Table 1.

Examination of these results confirms that the higher percentages of scores were in "neutral" for seven items: "I can use technology to determine student's needs related to a content area in the pre-teaching process", 1(5.3\%) of teachers answered "strongly agree", 3(15.8\%) of teachers answered "disagree", $8(42.1 \%)$ of teachers answered "neutral", $5(26.3 \%)$ of teachers answered "agree" and $2(10.5 \%)$ of teachers answered "strongly agree" with Mean score $(\mathrm{M}=3.21)$ and Std. Deviation $(\mathrm{SD}=1.07)$. On the item "I cannot plan the teaching and learning process according to available technological resources" $8((42.1 \%)$ of teachers answered "neutral", 4(21.1\%) of teachers answered "agree" and 7(36.8\%) of teachers answered "strongly agree" with the statement, with Mean score $(\mathrm{M}=3.95)$ and Std. Deviation $(\mathrm{SD}=0.91)$. In another item, "I can develop appropriate English language assessment tools by using technology", 1(5.3\%) of teachers answered "strongly disagree", 2(10.5\%) of teachers answered "disagree", $7(36.8 \%)$ of teachers answered "neutral", 6(31.6\%) of teachers answered "agree" and $3(15.8 \%)$ of teachers answered "strongly agree" with the statement with Mean score $(M=3.42)$ and Std. Deviation $(\mathrm{SD}=(1.07)$. On the statement, "I can implement effective classroom management in the teaching and learning process in which technology is used", results showed that 2(10.5\%) of teachers answered "agree", 7(36.8\%) of teachers answered "neutral", 5(26.3\%) of teachers answered "disagree" and $5(26.3 \%)$ of teacher participants answered "strongly disagree" with Mean score $(\mathrm{M}=3.68)$ and Std. Deviation ( $\mathrm{SD}=1.003)$. Similarly, on the item, "I can follow the teaching profession's codes of ethics in 
Michael Odoyo Ogalo et al., Sch J Arts Humanit Soc Sci, Jan, 2022; 10(1): 9-23

online educational environment (Web CT, Moodle)" $1(5.3 \%)$ of teachers answered "strongly disagree", $1(5.3 \%)$ of teachers answered "disagree", $5(36.8 \%)$ of teachers answered "neutral", $5(36.8 \%)$ of teachers answered "agree" and 3(15.8\%) of teachers in this study answered "strongly agree" with mean score $(\mathrm{M}=3.53)$ and Std. Deviation (SD=1.02).

In addition, the item, "I can troubleshoot any kind of problem that may occur while using technology in any phase of the teaching-learning process" (11.1\%) of teachers answered "strongly disagree", 3(16.7\%) of teachers answered "disagree", $8(44.4 \%)$ of teachers answered "neutral" and 5(27.8\%) of teachers answered "agree", with Mean score $(\mathrm{M}=3.37)$ and Std. Deviation $(\mathrm{SD}=(0.83)$. Furthermore, on the item "I can use technology to find solutions to problems (structuring, updating and relating the content to real-life)" $3(15.8 \%)$ of teachers answered "agree" $7(36.8 \%)$ of teachers answered "neutral" $8(42.1 \%)$ of teachers answered "disagree" and 1(5.3\%) of teachers answered "strongly disagree" with the statement, with Mean score $(\mathrm{M}=3.37)$ and Std. Deviation $(\mathrm{SD}=(0.83)$. Regarding the item, "I cannot use technology to develop language activities based on students' needs to enrich the teaching and learning process" the majority 9(47\%) of the teachers agreed with the item. The majority of the teachers $11(58 \%)$ strongly agreed that they can cooperate with other disciplines regarding the use of technology to solve problems encountered in the process of presenting content. In addition, the majority $9(47 \%)$ of the teachers strongly agreed with the statement "I cannot become a leader in spreading the use of technological innovation in my future teaching community." Overall, more than half of teachers of English "agreed" and "strongly agreed" with most statements as indicated with a mean of 3.5 and above. On the other hand, the majority of teachers according to this research question answered "neutral". Examining these results as shown by this response "neutral", I interpreted that majority of teachers in this study were not aware of their technological pedagogical knowledge. In other words, teachers in this study did not know about their TPK levels and, therefore, did not have adequate TPK for the integration of ICTs in teaching English. Table 1 gives a summary of this information.

Table 1: The Extent of Teachers' ICTs integration (Pedagogy) indicated by (TPK) Scale

\begin{tabular}{|c|c|c|c|c|c|c|}
\hline \multirow[t]{2}{*}{ Statements } & SD & D & $\mathbf{N}$ & $\mathbf{A}$ & SA & \multirow[t]{2}{*}{ M (SD) } \\
\hline & $\mathbf{N}(\%)$ & $\mathbf{N}(\%)$ & $\mathbf{N}(\%)$ & $\mathbf{N}(\%)$ & $\mathbf{N}(\%)$ & \\
\hline $\begin{array}{l}\text { I cannot update an instructional material (paper- } \\
\text { based, electronic or multimedia materials, etc.) } \\
\text { based on the needs (students, environment, } \\
\text { duration etc.) by using technology }\end{array}$ & $3(15.8)$ & $3(15.8)$ & $3(15.8)$ & $7(36.8)$ & $3(15.8)$ & $3.21(1.36)$ \\
\hline $\begin{array}{l}\text { I cannot use technology to determine student's } \\
\text { needs related to a content area in the pre-teaching } \\
\text { process }\end{array}$ & $1(5.3)$ & $3(15.8)$ & $8(42.1)$ & $5(26.3)$ & $2(10.5)$ & $3.21(1.07)$ \\
\hline $\begin{array}{l}\text { I cannot use technology to develop language } \\
\text { activities based on students' needs to enrich the } \\
\text { teaching and learning process }\end{array}$ & $1(5.3)$ & $2(10.5)$ & $4(21.1)$ & $9(47.4)$ & $3(15.8)$ & $3.58(1.07)$ \\
\hline $\begin{array}{l}\text { I cannot plan the teaching and learning process } \\
\text { according to available technological resources }\end{array}$ & 0 & 0 & $8(42.1)$ & $4(21.1)$ & $7(36.8)$ & $3.95(0.91)$ \\
\hline $\begin{array}{l}\text { I cannot develop appropriate English language } \\
\text { assessment tools by using technology }\end{array}$ & $1(5.3)$ & $2(10.5)$ & $7(36.8)$ & $6(31.6)$ & $3(15.8)$ & $3.42(1.07)$ \\
\hline $\begin{array}{l}\text { I can implement effective classroom management } \\
\text { in the teaching and learning process in which } \\
\text { technology is used }\end{array}$ & 0 & $2(10.5)$ & $7(36.8)$ & $5(26.3)$ & $5(26.3)$ & $3.68(1.003)$ \\
\hline $\begin{array}{l}\text { I can assess whether students have the appropriate } \\
\text { content knowledge by using technology }\end{array}$ & $1(5.3)$ & $4(21.1)$ & $3(15.8)$ & $8(42.1)$ & $3(15.8)$ & $3.42(1.17)$ \\
\hline $\begin{array}{l}\text { I can apply instructional approaches and methods } \\
\text { appropriate to individual differences with the help } \\
\text { of technology }\end{array}$ & $2(10.5)$ & $2(10.5)$ & $5(26.3)$ & $8(42.1)$ & $2(10.5)$ & $3.32(1.16)$ \\
\hline $\begin{array}{l}\text { I cannot use technology for implementing } \\
\text { language activities such as homework and } \\
\text { projects }\end{array}$ & $2(10.5)$ & $1(5.3)$ & $2(10.5)$ & $8(42.1)$ & $6(31.6)$ & $3.79(1.27)$ \\
\hline $\begin{array}{l}\text { I can use technology-based communication } \\
\text { tools(forum, chats, email in the instructional } \\
\text { process }\end{array}$ & 0 & $4(21.1)$ & $4(21.1)$ & $6(31.6)$ & $5(26.3)$ & $3.63(1.12)$ \\
\hline $\begin{array}{l}\text { I can be a suitable model for the students in } \\
\text { following codes of ethics for the use of }\end{array}$ & $1(5.3)$ & $3(15.8)$ & $4(21.1)$ & $6(31.8)$ & $5(26.3)$ & $3.58(1.22)$ \\
\hline
\end{tabular}


Michael Odoyo Ogalo et al., Sch J Arts Humanit Soc Sci, Jan, 2022; 10(1): 9-23

\begin{tabular}{|c|c|c|c|c|c|c|}
\hline \multirow[t]{2}{*}{ Statements } & SD & D & $\mathbf{N}$ & $\mathbf{A}$ & SA & \multirow[t]{2}{*}{ M (SD) } \\
\hline & $\mathbf{N}(\%)$ & $\mathbf{N}(\%)$ & $\mathbf{N}(\%)$ & $\mathbf{N}(\%)$ & $\mathbf{N}(\%)$ & \\
\hline \multicolumn{7}{|l|}{ technology in English language teaching } \\
\hline $\begin{array}{l}\text { I cannot use innovative technology (Facebook, } \\
\text { Twitter, blogs)to support the English language } \\
\text { teaching and learning process }\end{array}$ & 0 & 0 & $4(21.1)$ & $8(42.1)$ & $7(36.8)$ & $4.16(0.77)$ \\
\hline $\begin{array}{l}\text { I cannot use technology to update my knowledge } \\
\text { and skills in the content areas that I will teach }\end{array}$ & 0 & $1(5.3)$ & 0 & $6(31.6)$ & $12(63.2)$ & $4.53(0.77)$ \\
\hline $\begin{array}{l}\text { I can update my technological knowledge for the } \\
\text { English teaching process }\end{array}$ & 0 & 0 & $2(10.5)$ & $8(42.1)$ & $9(47.4)$ & $4.37(0.68)$ \\
\hline $\begin{array}{l}\text { I cannot use technology in every phase of the } \\
\text { teaching and learning process by considering the } \\
\text { copyright issues (licenses) }\end{array}$ & $1(5.6)$ & $5(27.8)$ & $3(16.7)$ & $6(33.3)$ & $3(16.7)$ & $3.28(1.23)$ \\
\hline $\begin{array}{l}\text { I can follow the teaching profession's codes of } \\
\text { ethics in an online educational environment (Web } \\
\text { CT, Moodle) }\end{array}$ & $1(5.3)$ & $1(5.3)$ & $7(36.8)$ & $7(36.8)$ & $3(15.8)$ & $3.53(1.02)$ \\
\hline $\begin{array}{l}\text { I can guide students by leading them to valid and } \\
\text { reliable digital sources }\end{array}$ & 0 & $1(5.3)$ & $5(26.3)$ & $9(47.4)$ & $4(21.1)$ & $3.84(0.83)$ \\
\hline $\begin{array}{l}\text { I can behave ethically regarding the appropriate } \\
\text { use of technology in educational environments }\end{array}$ & 0 & $3(16.7)$ & $2(11.1)$ & 7 (38.9) & $6(33.3)$ & $3.89(1.08)$ \\
\hline $\begin{array}{l}\text { I cannot troubleshoot any kind of problem that } \\
\text { may occur while using technology in any phase of } \\
\text { the teaching-learning process }\end{array}$ & $2(11.1)$ & $3(16.7)$ & $8(44.4)$ & $5(27.8)$ & 0 & $2.89(0.96)$ \\
\hline $\begin{array}{l}\text { I can use technology to find solutions to problems } \\
\text { (structuring, updating and relating the content to } \\
\text { real life) }\end{array}$ & 0 & $3(15.8)$ & $7(36.8)$ & $8(42.1)$ & $1(5.3)$ & $3.37(0.83)$ \\
\hline $\begin{array}{l}\text { I cannot become a leader in spreading the use of } \\
\text { technological innovation in my future teaching } \\
\text { community }\end{array}$ & 0 & $2(10.5)$ & $3(15.8)$ & $9(47.4)$ & $5(26.3)$ & $3.89(0.94)$ \\
\hline $\begin{array}{l}\text { I can cooperate with other disciplines regarding } \\
\text { the use of technology to solve problems } \\
\text { encountered in the process of presenting content }\end{array}$ & 0 & $1(5.3)$ & $2(10.5)$ & $11(57.9)$ & $5(26.3)$ & $4.05(0.78)$ \\
\hline
\end{tabular}

Through the third objective, I sought out to investigate the technological pedagogical knowledge of a teacher of English for ICT integration. In other words, the researcher sought to further establish teachers of English technological pedagogical knowledge (TPK) levels to be successfully and confidently integrate ICT in their English language lessons. I interviewed teachers to find out levels of ICT training, strategies used for ICT integration and content areas that they apply ICT tools in their instructions. One of the questions in the interview guide was, "Have you taken any ICT training and to what extent have you applied that knowledge in teaching English"? The researcher further wanted to establish teachers' ICT training and professional development to be able to integrate ICT in teaching. Interview results revealed that the majority of teachers in this study agreed that ICT training and professional development is a major factor influencing their efforts to use ICT in teaching English. From the results, the researcher observed that the majority $(\mathrm{N}=16)$ had taken or attended some ICT training programmes.

On the other hand, the majority of teacher participants indicated that they had trained on basic computer packages: basic computer skills, MS Words,
PowerPoint and general ICT skills. Findings further revealed that only a small number $(\mathrm{N}=3)$ had taken their training in established computer training colleges. In addition, there were only four teachers who reported that they had been sponsored by the Ministry of Education to take ICT training. Two teachers had attained a Diploma certificate in IT, while the other two had attained a Certificate in computer/ICT. Regarding the question of whether teachers applied the knowledge gained through these training to integrate ICT in teaching English, one teacher reported that she applied ICT occasionally (TR1). She further explained how she had been struggling to integrate ICT into her English teaching for about three years. She also indicated that using ICT in teaching English allowed her to access more materials from the Internet; she further indicated that she used a projector and PowerPoint to present her English lessons using grammar video clips. She stated: I use PowerPoint presentations to deliver English content. I also use computing in the assessment of language skills, pronunciation, writing and I use technology to extend students' thoughts about language. I urge them to pronounce and transcribe words as others listen from CDs (TR1) 
Michael Odoyo Ogalo et al., Sch J Arts Humanit Soc Sci, Jan, 2022; 10(1): 9-23

Similarly, the researcher asked teachers the following question "What steps have you taken to develop your technical skills for effectively and competently integrating ICT in English language instructions?" Results revealed that teachers of English were unanimous in support of ICT training and professional development as an effort of improving teacher technological pedagogical knowledge for ICT integration in teaching English. To this effect, sixteen teachers indicated that they had taken ICT training courses. Three teachers reported they had not taken ICT training but indicated they were in the process to register with various ICT training institutions to train as they find it necessary for educational purposes. Table 2 summarizes teachers' interview responses.

Table 2: Teachers' Classification According to ICT Training

\begin{tabular}{|l|l|l|l|}
\hline Teacher & ICT Training & Institution/Ministry & ICT Course/Levels \\
\hline TR 1 & Yes & No & Basic Comp. Skills \\
\hline TR 2 & Yes & Yes & Cert. in ICT \\
\hline TR 3 & No & None & Basic Comp. Skills \\
\hline TR 4 & Yes & Computer Training Col. & Cert. in ICT \\
\hline TR 5 & Yes & Computer Training Col. & Basic Comp. Applications \\
\hline TR 6 & Yes & Computers in computer Lab & Diploma in IT \\
\hline TR 7 & Yes & Ministry (MoES \&T) & Diploma in ICT \\
\hline TR 8 & Yes & Computer Training Col. & Projector, Mobile Phone \\
\hline TR 9 & Yes & Computer Training Col. & None \\
\hline TR 10 & No & None & None \\
\hline TR 11 & Yes & Ministry (MoES \& T) & General ICT Applications \\
\hline TR 12 & Yes & None & General ICT Applications \\
\hline TR 13 & No & None & None \\
\hline TR 14 & Yes & None & Basic Comp. Skills \\
\hline TR 15 & Yes & None & Basic Comp. Applications \\
\hline TR 16 & Yes & None & Comp. Packages \\
\hline TR 17 & Yes & None & Comp. Packages \\
\hline TR 18 & Yes & Comp. Training Col & Cert. in Computer \\
\hline TR 19 & Yes & None & Basic Comp. Skills \\
\hline
\end{tabular}

Key:

Cert.Certificate

Col. College

Comp. Computer

MoES \& T Ministry of Education Science and Technology

TR Teacher

Research objective three aimed to investigate the technological pedagogical knowledge (TPK) of a teacher of English for ICT integration. Pedagogy is a generic form of knowledge that is involved in all issues of student learning, classroom management, lesson plan development and implementation, and student evaluation. It includes knowledge about techniques or methods to be used in the classroom; the nature of the target audience; and strategies for evaluating student understanding (Deshmukh, 2013). A teacher with deep pedagogical knowledge understands how students construct knowledge, acquire skills, and develop habits of mind and positive dispositions towards learning. There are two main aspects where ICT is used as a tool for teaching English and English is taught via ICT. Both aspects demand modification in teachers' pedagogical approaches. An effective blend of these two methodologies can justify the efficacy of using a wide range of ICT applications. English language teaching (ELT) practitioners are expected to teach content knowledge using a pragmatic pedagogical method in indissoluble conjunction with ICT skills and knowledge. The quality use of ICTs and the use with a pedagogical incentive become urgent where English materials should be the only focus and ICT facilities become pedagogical and environment agents (Deshmukh, 2013). In this study, TPK encompasses how teaching and learning change when particular technologies are used. In teacher research, pedagogical knowledge (PK) is considered an overall knowledge of pedagogy, which is a broad area of knowledge. The researcher examined responses to find out instances of teachers' technological pedagogical knowledge (TPK) to ascertain specific forms of TPK underpinned teachers' decisions. The results showed that during the teaching of English, teachers drew upon only traditional pedagogical knowledge in two ways: First, teachers' knowledge on setting dates and schedules for teaching and making decisions about time management. Second, the TPK scale showed that teachers' understanding of features, characteristics of affordances of particular technological tools (such as PowerPoint, YouTube, Websites and the Internet). A teacher reported: 
Michael Odoyo Ogalo et al., Sch J Arts Humanit Soc Sci, Jan, 2022; 10(1): 9-23

"I ask students to search the Internet for correct sounds and correct word pronunciation. I try to do this in most lessons as part of their homework as well. However, not all students could access computers and the internet at school because of scarcity; I asked them to work in groups. In general, I consider encouraging them to Google search the Internet to look for information on language related to the lesson. I find this important for the students to improve their language skills, proficiencies and competencies" (TR6).

The above statement is specifically about the Internet and its uses for services such as Google sites, Web sites and other tools supported by Google or Internet. Teachers also seem to extensively refer to other tools sometimes during their teaching indicating teachers' knowledge of these tools. The study found out that teachers of English drew on TPK in two forms when teaching: First, TPK can refer to teachers' use of different technological tools and resources for teaching. For example, a teacher reported:

"Sometimes I asked students to google search for information about a particular topic related to the lesson to be discussed. I targeted them by searching the Internet for relevant English materials and added that ICT should be responsive to students' needs, tendencies and interests. Students learn new English skills such as proper pronunciation, spellings and basic grammar rules at different levels language learning" (TR4).

The above statement shows that teachers sometimes referred to using different kinds of ICTs to assess students' knowledge and skills such as using online decision forums for collaboration and creation of digital storytelling projects and the creation of Google sites to assess students' design skills. For example, students are sometimes given online discussions and the teacher sets up a discussion forum for them. This means that an important part of TPK is developing creative flexibility with available tools to repurpose them for specific pedagogical purposes. For example, teachers design MS Office for English language environment, designing Web-based technologies, such as blogs or design podcasts for purpose of communication, and social networking. Second, teachers indicated that they could plan the teaching and learning process according to available technological resources and could use these technologies to determine student's needs related to a content area in the pre-teaching process. Results from qualitative results have revealed that teachers applied radio cassettes to enhance the teaching of expository writing, especially in the teaching of essay writing in English (TR.4). She further indicated that she used ICT tools in the teaching of pronunciation, language skills and to some extent grammar items. To be able to do these, teachers need strong foundation skills in technological pedagogical knowledge. Second, findings revealed that a few teachers had an average TPK level, while a majority of the participant teachers had low levels of TPK knowledge. These results are in parallel with research done by Harbi, (2014), who found that under half of Saudi High school teachers $(\mathrm{N}=13)$ showed a high level of TPK knowledge, about a third $(88 ; 35 \%)$ had an average level, while only $20 \%$ of the participants had low levels of TPK knowledge. According to Beaudin and Hadden (2004), the critical reflection on the use of ICT tools in teaching and learning would help the teachers to improve their pedagogical skills. Similarly, the findings revealed that the majority of teachers of English in secondary schools in Nairobi County lack technological pedagogical knowledge (TPK). Findings from the interview accounts indicated that the majority of teachers were not satisfied with their technological pedagogical knowledge necessary for the ICT integration in teaching English. Koehler and Mishra (2009) explained and affirmed that TPK is an understanding of how teaching and learning can change when particular technologies are used in particular ways.

Mishra and Koehler (2007) argued that effective teaching with technology requires an understanding of pedagogical knowledge that use technologies in constructive ways to teach content corroborates this position. Similarly, findings revealed differences among teachers of English in terms of their TPK. While TR16 and TR17 described themselves as having acquired general ICT skills, they lacked sufficient TPK knowledge. This study further found that all participants who were at the Inaction stage also had limited or no TPK. While teachers who were at the Investigation and Application stages also had low to average levels of TPK and low levels of effectiveness in ICT integration in teaching the English language. These findings are supported by the theory in which the greater TPACK a teacher has, the more effective ICT integration is demonstrated by the teacher (Koehler and Mishra, 2006).

On the other hand, the majority of teachers reported that they knew using the available presentation devices browsing the Internet for resources related to their English language contents, and applying E-mailing and Microsoft Office software applications, such as Word and PowerPoint. Similarly, TR3 indicated that he knew MS Word, PowerPoint and Excel applications. Similarly, TR4 reported that she knew how to operate and plug in her laptop in the classroom and mount a projector to present slides using PowerPoint presentations. From these results, the researcher construed that these skills certify the essential skills, such as computer essentials skills, information searching, online communication and E-mailing, word processing and excel. Moreover, TR9, who is at the Inaction level, mentioned that she had done a general computer course. It points out that having technological knowledge alone was not sufficient for the teachers of English to achieve effective ICT integration. Furthermore, these results have revealed that in this study, teachers' knowledge on ICT fell between low 
Michael Odoyo Ogalo et al., Sch J Arts Humanit Soc Sci, Jan, 2022; 10(1): 9-23

and moderate levels as they were only able to use applications such as MS Word (Word processing), PowerPoint, and E-mailing as these are the main applications which are commonly and often used for teaching. These results are consistent with research done by Rosnaini \& Mohd Arif (2010) who found that the majority group of teachers were only knowledgeable on certain applications such as word processing and internet browsing. Similarly, findings from interview counts showed that most teachers lacked sufficient knowledge on technology that could enable them to effectively integrate ICTs into their English classroom instructions. These findings are supported by a study by Melor (2007) and Samuel and Zaituni (2007) whose findings concluded that Malaysian ESL teachers, though, had positive attitudes towards ICT integration, lacked skills as they were not well versed with many new software applications.

Kandasamy and Mohd Shah, (2013) pointed out that the successful implementation of ICT integration in the teaching and learning of the English language needs full cooperation and support from the school administration, positive attitude of teachers of English, continuous training to update teachers' ICT skills, and training on how to use ICT tools appropriately. Similar support is from Koehler and Mishra (2005) who posit that for a teacher to successfully integrate technology, it is important to teach technology in contexts that represent the high connections between technology, content and pedagogy. They reported that participants in their design teams showed a significant shift towards developing technological pedagogical content knowledge (TPACK), involving the development of a deeper understanding of the complex string of relationships between content, pedagogy and technology and the contexts within which they function. Furthermore, findings in this study revealed that there were limited training programmes in place among the participating secondary school teachers of English, leading to the majority of these teachers falling under low levels of ICT skills and low levels in TPK. These results are in parallel with findings of many studies in different developed countries; (Archambault and Crippen, 2009; Doukakis, et al., 2010; Karadeniz and Vatanartiran, 2013) where teachers demonstrated a high level of TPK scale. Bradl (2002) suggested that any type of technology used in language classrooms starts from providing teachers with possible ways to incorporate technology into the curriculum as well as offering ideas for developing a pedagogically welldesigned lesson. Overall, the findings revealed that TPACK constructs were not referred to by teachers in their English language instructions.

\section{RECOMMENDATIONS}

The study recommends the following:

\section{Teachers of English}

Universal basic ICT training for secondary school teachers of English in the country should be rolled out. Teachers of English should be encouraged, trained in basic and advanced ICT skills to be technologically empowered to integrate ICT in teaching. It is suggested that teachers' knowledge about technology be addressed as a key component in the process of ICT integration.

Professional and pre-service language teacher development programmes should also focus on coupling changes in teachers' technological pedagogical knowledge and philosophies for teaching and learning with their training on how to appropriately and effectively integrate ICT tools with their studies.

\section{Ministry of Education}

Building strong ICT infrastructure foundations in secondary schools are essential in facilitating ICTs integration in teaching English in secondary schools. The educational stakeholders should strive to articulate an ICT implementation plan by providing detailed and clear policies required to translate the language teacher educational vision and goal into reality.

\section{CONCLUSIONS}

The majority of teachers of English in this study sat in lower critical use border: Inaction and Investigation stages on the Teacher Professional ICT Attribute Framework, accounting for between 0-20\% and $20-40 \%$ respectively. TPACK are key factors that could influence teachers' enthusiasm to integrate ICTs in their English language instructions. Lack of support and motivation at schools, government and limited access to Internet and ICT resources, limited ICT facilities, infrastructure and lack of ICT training are some of the challenges teachers faced for ICT integration in their English language classrooms. The majority of teachers of English in this study did not have adequate ICT training and therefore had low TPK levels

\section{REFERENCES}

1. Albirini, A. (2006). Teachers' attitudes toward information and communication technologies: The Syrian EFL teachers. Computers \& Education, 47(4), 373-398.

2. Al-Otaawi, S. M. (2002). The perceptions of Administrators and teachers in utilizing information technology in instruction, administrative work, technology planning and staff development in Saudi Arabia. (Doctoral dissertation, Ohio University, 2002).

3. Archambault, L. \& Crippen, K. (2009).Examining TPACK among K-12 online distance educators in 
Michael Odoyo Ogalo et al., Sch J Arts Humanit Soc Sci, Jan, 2022; 10(1): 9-23

the United States. Contemporary Issues in Technology and Teacher Education. 9(1), 71-88.

4. Attia, M. M. (2011). Teacher Cognition and the use of Technology in Teaching Arabic to Speakers of other Languages. A PhD thesis, The University of Manchester, UK.

5. Balcon, P. (2003). ICT in Education System in Europe. Retrieved from http://www.elearningeuropa.info/directory/index.ph p?doc_id $=949 \&$ doclng $=6 \&$ page $=$ doc

6. Balanskat, A. B., \& Kefala, S. (2006). A review of studies of ICT impact on schools in Europe. European Schoolnet. Brussels, European Community.

7. Bangimlas, K. A. (2009). Barriers to the successful integration of ICT in teaching and learning environments: A review of the literature. Euroasia Journal of Mathematics, Science \& Technology Education, 5(3), 235-245.

8. BECTA. (2004). A review of research literature on barriers to the uptake of ICT by teachers. Coventry UK: British Educational Communications and Technology Agency.

9. BECTA. (2009). Harnessing Technology Review 2009. The role of technology in education and skills. Coventry UK: British Educational Communications and Technology Agency.

10. Belland, B. R. (2009). Using the theory of habitus to move beyond the study of barriers to technology integration. Computers and Education, 52(2), 353364.

11. Borg, S. (2009). Language teacher cognition. In A. Burns \& J. Richards (Eds.), Second language teacher education (pp. 163-171). New York: CUP.

12. Bransford, J. D., Brown, A. L., \& Cooking, R. R. (2002). How people learn: brain, mind, experience, and school (expanded Ed.) Washington, DC, USA: National Academies Press.

13. Brunk, J. D. (2008). Factors affecting the level of technology implementation by teachers in elementary schools. (Ed. D., The University of Oklahoma, 2008).

14. Chai, C. S., Koh, J. H. L., \& Tsai, C.C. (2010).Facilitating pre-service teachers' development of technological, pedagogical, and content knowledge (TPACK). Educational Technology \& Society, 13 (4), 63-73.

15. Cox, S., \& Graham, C. R. (2009). Diagramming TPACK in practice. Using an elaborated model of the TPACK framework to analyse and depict teacher knowledge. TechTrends. Linking Research Practice to improve Learning, 53 (5), 60-69. Doi: 10, 1007/511528.009-0327-1

16. Demetriadis, S., Barbas, A., Molohides, A., Palaigeorgiou, G., Psillos, D., Vlahavas, I., Tsoukalas, I., Pombortsis, A. (2003). "Cultures in negotiation": Teachers' acceptance/resistance attitudes considering the infusion of technology into schools. Computers \& Education, 41(1), 1937.
17. Deshmukh, N. K. (2013).A Pedagogical Approach to ICT Integration in English Language Teaching .Shri Datta Meghe Politechnic, Wanadongri, Nagpur..

18. Dexter, S., Anderson, R. E., \& Becker, H. J. (1999). Teachers' views of computers as catalysts for change in their teaching practice. Journal of Research on Computing in Education, 31, 221-239.

19. De Winter, J., Winterbottom, M. \& Wilson, E. (2010). Developing a user guide to integrating new technologies in science teaching and learning: teachers' and pupils' perceptions of their affordances to learning technologies in their selfdirected study'. ALT-J 16(1), p.5-14.

20. Doukakis, S., Psaltidou, A., Stavraki, A., Adamopoulos, N., Tsiotakis, P., \& Stergou, S. (2010). Measuring the technological pedagogical content knowledge (TPACK) of in-service teachers of computer science who teach algorithms and programming in upper secondary education. Paper presented at the Readings in Technology and Education. Proceedings of ICICTE.

21. Ertmer, P. A. (2005).Teacher pedagogical beliefs: The final frontier in our quest for technology integration. Educational technology Research and Development, 53(4), 25-39.

22. European Commission (2013).Digital literacy policies. Digital Agenda for Europe. Available online at: http//ec.europa.eu/digital-agenda

23. Felix, U. (2002). The web as a vehicle for constructivist approaches in language teaching. ReCALL, 14(1), 2-15.

24. Gao, J., \& Hargis, J. (2010). Promoting technology-assisted active learning in computer science education. The Journal of Effective Teaching, 10(2), 81-93.

25. Hew, K., \& Brush, T. (2007). Integrating technology into K-12 teaching and learning: current knowledge gaps and recommendations for future research. Educational Technology Research and Development, 55(3), 223-252. Doi: 10.1007/s11423-006-9022-5

26. Inan, F. A., Lowther, D. L., Ross, S. M., \& Strahl, D. (2010). Partten of classroom activities during students' use of computers: Relations between instructional strategies and computer applications. Teaching and Teacher Education, 10(4), 540-546.

27. Jimoyiannis, A., \& Komis, V. (2014).Exploring secondary education teachers' attitudes and beliefs towards ICT adoption in education, Themes in Education, 7(2), 181-204.

28. Kandasamy, M., Parilah Bt Hj \& Shah, M. (2013). Knowledge, Attitude and Use of ICT among ESL Teachers. GSE Journal of Education (e-ISBN 97811768-0-1)

29. Kashorda, M., Waema, T., Omosa, M., \& Ilori, V. (2007). E-Readiness: Survey of Higher Education Network (KENET). Nairobi

30. Koehler, M. J., Mishra, P., \& Yahya, K. (2007). Tracing the development of teacher knowledge in a 
Michael Odoyo Ogalo et al., Sch J Arts Humanit Soc Sci, Jan, 2022; 10(1): 9-23

design seminar. Integrating content, pedagogy and technology. Computers \& Education, 49 (3), 740762

31. Lane, J. M. (2012). Developing the vision: Preparing teachers to deliver a digital world -class education system. Australian Journal of teacher education 37(4), 59-74.

32. Lankshear, C. \& Knobel, M. (2006). New Literacies: Everyday practices and classroom learning (Second Edition) Maidenhead. Open University Press.

33. Lin, J., Wang, P. Y., \& Lin, I. (2012). Pedagogy* technology: A two-dimensional model for teachers' ICT integration. British Journal of Educational technology, 43(1), 97-108.

34. Lovesless, A., \& Dore, B., (2003). ICT in the primary school. Learning and Teaching with ICT. Buckingham: Open University Press.

35. Lee, M. H. \& Tsai, C. C. (2010). Exploring teachers' perceived self-efficacy and technological pedagogical content knowledge with respect to educational use of the World Wide Web. Instructional Science, 38 (1), 1-21.

36. Lefebvre, S. Duesdelin, C., \& Loiselle, J. (2006). ICT implementation stages of primary school teachers: The practices and conceptions of teaching and learning. Paper presented at the Australian Association for Research in Education National Conference, Aldelaide, Australia.

37. Manyasi, N. B. (2012). English Language Teachers' Cognition of the Teaching of Reading for Nationhood: A Study of Secondary School Teachers in Uasin Gishu County in Kenya.

38. Melor Md Yunus (2007). Malaysian ESL teachers' use of ICT in their classrooms: expectations and realities. RECALL: The Journal of EUROCALL, 9(1), 79-95.

39. Mishra, M. \& Koehler, P. (2006).Technological pedagogical content knowledge: A framework for integrating technology in teacher knowledge. Teacher College record, 108 (6), 1017-1054.

40. Niederhauser, D. S., \& Stoddart, T. (2001).Teachers' instructional perspectives and use of educational software. Teaching and Teacher Education, 17(1), 15-31

41. Njagi, R. \& Oboko, R. (2013). A Monitoring and Evaluation Framework for the Integration of ICTs in Teaching and Learning in Primary schools in Kenya. Journal of Education and Practice, 4, 12.

42. Polly, D., Mims, C., Shephard, C. E., \& Inan, F. (2010). Evidence of Impact: transforming teacher education with preparing tomorrow's teachers to teach technology (PT3) grants. Teaching and teacher education, 26, 863-870. Retrieved from: http://www.sciencedirect.com.millinnium.lib.intust. edu.tor/science/article/pii/S0742051X09002224

43. Rosnaini, M., \& Mohd, A. H. (2010). Impatic of Training and Experience in using ICT on In-service Teachers' Basic ICT Literacy. Malaysian Journal of Education Technology, 10(2).

44. Samuel, R. J. \& Zaitun, A. B. (2007). Do Teachers have adequate ICT Resources tools and the Right ICT Skills in integrating ICT Tools in the teaching and learning of English language in Malaysian schools?

45. Shulman, L. S. (1986). Those who understand knowledge growth in teaching.Educational Researcher, 15 (2).

46. Suwannasom, T. (2010).Teacher cognition about Technology-mediated EFL instruction in the Thai tertiary context. A PhD thesis. Massey University, New Zealand.

47. Tondeuer, J., Hermans, R., Van Beek, J., \& Valcke, M. (2008).Exploring the link between teachers' educational belief profiles and different types of computer use in the classroom. Computers in Human Behaviour, 24(6), 2541-2553.

48. Van Break, J. (2001). Factors influencing the use of computer Mediated communication by teachers in secondary schools. Computer \& Education, 36 (1), 41-57.

49. Wanjala, A. S. (2013). Teachers' Perception on the use of ICT in the administration of public secondary schools in Kimilili District, Bungoma County, Kenya. (Unpulished Thesis).

50. Wozney, L., Venkatesh, V. \& Abrami, P. C. (2006).Implementing computer technologies: Teachers' perceptions and practices. Journal of Technology and Teacher education, 14(1), 173207.

51. Zhao, Y., \& Frank, K. A. (2003). Factors affecting technology uses in schools: An ecological perspective. American Educational Research Journal, 40(4), 807-840. 